\title{
RELATIONSHIPIS BETWEEN BLOOD HORMONES AND METABOLITES IN SIMMENTAL DAIRY COWS DURING TRANSITION PERIOD AND MID LACTATION
}

\author{
Radojica Đoković ${ }^{1}$ Zoran Ilić². Vladimir Kurćubić ${ }^{1}$ Milun Petrović ${ }^{1}$ Marko Cincović3 \\ Miroslav Lalović . Boban Jašović \\ ${ }^{1}$ University of Kragujevac, Department of Animal Science, Faculty of Agronomy \\ Čačak, Cara Dušana 34, 32000 Čačak, Serbia, \\ ${ }^{2}$ University of Priština, Department of Animal Science, Faculty of Agronomy, \\ Jelene Anžujske bb, 37 200, Lešak, Serbia, \\ ${ }^{3}$ University of Novi Sad, Department of Veterinary Medicine, Faculty of Agriculture, \\ Trg Dositeja Obradovića 8, 21 000, Novi Sad, Serbia, \\ ${ }^{4}$ University of East Sarajevo, Department of Animal Science, Faculty of Agriculture, \\ Vuka Karadžića 30, 71123 Istočno Novo Sarajevo, Bosnia and Herzegovina \\ radojicadjokovic@gmail.com
}

\begin{abstract}
The main purpose of this article, was investigation metabolic and endocrine status in Simmental dairy cows during transition period and mid lactation, based on the relationships between blood growth hormone (GH), insulin, triiodothironine (T3), thyroxine (T4), glucose, beta-hydroxybutyrate (BHB), non-esterified fatty acids (NEFA) and triglycerides (TG). For the analysis were chosen 45 Simmental cows divided in three equal groups and each group was consist of fifteen cows: Group 1 was late pregnant cows, group 2 was early lactation cows and group 3 was mid lactation cows. Blood metabolic hormones as well as metabolites were analyzed and obtained results were recorded. Second group of early lactation cows have significant higher blood serum concentrations of $\mathrm{GH}(\mathrm{p}<0.05)$, NEFA $(\mathrm{p}<0.05)$ and BHB $(\mathrm{p}<0.05)$ and significant lower blood serum concentrations of insulin $(\mathrm{p}>0.05), \mathrm{T} 3(\mathrm{p}<0.05), \mathrm{T} 4$ $(\mathrm{p}>0.05)$, glucose $(\mathrm{p}<0.05)$ and TG $(\mathrm{p}<0.05)$ compared with the first group of late pregnancy cows and third group of mid lactation cows. Significant positive correlations $(\mathrm{p}<0.05)$ were noticeable between GH and NEFA, T3 and insulin, T3 and T4, glucose and T3, glucose and TG and negative $(\mathrm{p}<0.05)$ between glucose and NEFA and glucose and BHB. These hormonal and metabolic changes can be useful indicators of the metabolic and endocrine status of dairy cows.
\end{abstract}

Key words: Simmental dairy cows; blood hormones; blood metabolites

\section{ОДНОС МЕЃУ ХОРМОНИТЕ НА КРВТА И МЕТАБОЛИТИТЕ КАЈ СИМЕНТАЛСКИ МЛЕЧНИ КРАВИ ЗА ВРЕМЕ НА ПРЕОДНИОТ ПЕРИОД И СРЕДИНА НА ЛАКТАЦИЈАТА}

Главна цел на овој труд е проучување на метаболитичкиот и ендокриниот статус на сименталски млечни крави за време на преодниот период и средина на лактацијата, врз основа на односот помеѓу крвниот хормон за раст (GH), инсулинот, тријодотиронинот (T3), тироксинот (T4), глукозата, бета-хидроксибутиратот (BHB), неестерифицираните масни киселини (NEFA) и триглицеридите (TG). За анализа беа избрани 45 сименталски крави, поделени во три еднакви групи при што секоја група се состоеше од петнаесет крави: група 1 беа крави во доцна стелност, група 2 беа крави во рана лактација и група 3 беа крави во средина од лактацијата. Беа анализирани метаболитичките хормони на крвта и метаболитите, а добиените резултати беа евидентирани. Втората група на крави во рана лактација имаа значајно повисоки концентрации на GH во крвта $(\mathrm{p}<0.05)$, NEFA $(\mathrm{p}<0.05)$ и BНB $(\mathrm{p}<0.05)$ и значајно пониски серумски концентрации на инсулин во крвта (p>0.05), T3 (p<0.05), T4 (p>0.05), глукоза ( $<<0.05)$ и TG $(\mathrm{p}<0.05)$ во споредба со првата група на крави во доцна бременост и третата група на крави во средина од лактацијата. Значајно позитивни корелации $(\mathrm{p}<0.05)$ беа забележани меѓу GH и NEFA, T3 и инсулин, Т3 и T4, глукоза и T3, глукоза и TG и негативна 
$(\mathrm{p}<0.05)$ меѓу глукоза и NEFA и глукоза и ВНВ. Овие хормонални и метаболички промени може да бидат корисни индикатори за метаболитичкиот и ендокриниот статус на млечните крави.

Клучни зборови: сименталски млечни крави; крвни хормони; крвни метаболити

\section{INTRODUCTION}

Major changes in the hormonal regulation of metabolic functions in Simmental cows occur during the transitional period and early lactation. Parturition and lactogenesis are accompanied by many physiological changes that alleviate metabolic disturbance during critical period in order to maintenance homeostasis (Bauman and Currie, 1980). Adaptation of the endocrine system during the transitional period is the key factor in maintaining metabolic balance (Bauman and Currie, 1980; Aceves et al., 1985). GH stimulates lipolysis and lipid mobilization of adipose tissue during the negative energy balance (NEB) in postpartal period in Simmental cows, supplying energy for milk production. (Bauman and Vernon, 1993; Lucy et al., 2001). Simultaneously, plasma concentrations of insulin as another homeorhetic hormone, would be decreased in peripartal period, so nutrient supply to the udder will be affected (insulin resistence) (Bonczek et al., 1988; Tucker, 1994; Bell, 1995; Butler et al., 2003; Balogh et al., 2008). Thyroid hormones, primarily triiodothyronine (T3), play an important role in the regulation of energy metabolism. A decrease in thyroid hormone levels occurs in the blood of peripartal cows, particularly during early lactation, when body reserves are mobilized for the production of high amounts of milk (Bonczek et al., 1988; Tiirats, 1997; Huszenicza et al., 2002). NEB, lipomobilization and hypothyreoidism at the onset of lactation in Simmental cows are accompanied with tremendous changes in energy metabolism and oxidation processes, particularly in liver cells. Serum concentration of T3 and T4 are considered as indicators of adaptation (homeoretic adaptation) to NEB in early lactation dairy cows (Reist et al. 2002; Djoković et al. 2007). NEFA is the main blood indicators of lipomobilization in ruminants and $\mathrm{BHB}$ is indicator for ketogenesis in liver cells (Oetzel, 2004; Civelek et al., 2011; González et al., 2011). NEB and intensive lipomobilization from body depots induces an increase in both lipogenesis and ketogenesis, a decrease in gluconeogenesis in liver cells, and disturbance in the morphological and functional integrity of hepatocytes, leading to decreased blood levels of glucose, albumin, globulin, total cholesterol, TG and urea (Veenhuizen et al.,1991; Sevinc et al., 2003; Oetzel, 2004; Djoković et al., 2007).
The objective of the present study was to investigate the metabolic and endocrine status in Simmental cows during transition period and mid lactation based on correlation between blood hormones and biochemical metabolites.

\section{MATERIALS AND METHODS}

The experiment was carried out in Simmental dairy herd which have high genetic merit for milk production (220 Simmental cows). Cows were of similar body mass (600-650 kg), 4-6 years old, an average of 3 lactations with a mean milk yield of 65001 (calculated over 305 days) in the previous lactation. Clinically healthy cows were divided in three groups from the herd. Group 1 consisted of late pregnant cows $(n=15)$ from 25 to $1(13 \pm 9)$ days relative to partus, Group 2 included early lactation cows $(\mathrm{n}=15)$ during the first month of lactation (16 \pm 9 days), and Group 3 comprised mid lactation cows $(\mathrm{n}=15)$ between 3 to 5 months of lactation (115 \pm 29 days). The body condition scores (BCS) of the test cows were $3.85 \pm 0.65$ (Group 1, late pregnancy), $3.57 \pm 0.55$ (Group 2, early lactation) and $3.37 \pm 0.74$ (Group 3, mid lactation) (Ferguson et al., 1994). The experimental cows were kept in tie-stall barns. Diet and the housing facilities were adapted for research purposes. Diet was appropriate for energy requirement of late pregnancy, early and mid lactation cows. The ingredients and chemical composition of total mixed rations offered to late pregnant, early lactation and mid lactation dairy cows are given in Table 1 .

Blood samples were collected at 10:00 h or 4 to 6 hours after milking and feeding, by puncture of the jugular vein into sterile disposable test tubes. After clotting at $4^{\circ} \mathrm{C}$ and centrifugation $(1500 \mathrm{~g}, 10$ minutes, $4^{\circ} \mathrm{C}$ ), sera were carefully separated and stored at $-20^{\circ} \mathrm{C}$ until analysis. Blood samples collected with fluoride tubes, were immediately centrifuged in the same manner, and glucose concentrations in plasma was analysed. Serum concentrations of GH, insulin, T3 and T4 were determined by ELISA methods (Endocrine Technologies Inc. CA, USA) using Humareader Single plus (Human, Germany). 
Table 1

Ingredients and chemical composition of total mixed rations offered to late pregnant, early lactation and mid lactation dairy cows

\begin{tabular}{lccc}
\hline \hline & Late pregnant cows & Early lactation cows & Mid lactation cows \\
\hline Grass hay & - & - & 5 \\
Lucerne hay (kg) & 6 & 7 & 7 \\
Maize silage (30\% Dry Matter, DM) $(\mathrm{kg})$ & 15 & 20 & 30 \\
Concentrate (18\% crude proteins, CP) $(\mathrm{kg})$ & 3 & 5 & 8 \\
Dry Matter (DM) (kg) & 11.94 & 16.05 & 24.82 \\
Net Energy of Lactation (NEL) (MJ) & 65.25 & 87.15 & 130.23 \\
Crude Protein (CP) (\% of DM) & 12.55 & 13.58 & 13.38 \\
Rumen undegradable protein (RUP) (\% of CP) & 30.86 & 35.91 & 28.33 \\
Fat (\% of DM) & 3.27 & 3.09 & 3.14 \\
Fiber (\% of DM) & 25.82 & 23.26 & 24.33 \\
\hline \hline
\end{tabular}

The following blood metabolites were measured by colorimetric techniques using spectrophotometers Cobas Mira (Roche,Belgium) and Gilford Stasar III (Gilford, USA) according manufactuer instruction: BHB was measured using Fortress kits (USA), NEFA was analyzed using Randox kits (United Kingdom), glucose using Human kits (Germany), TG using Elitech kits (France). The statistical analysis of the obtained data was carried out by ANOVA-procedure (Statgraphic Centurion, Statpoint Technologies Inc.Warrenton, Va, Virginia, USA). The analysis of variance and LSD test were used to evaluate the probability of the significance of the statistical differences between mean parameter values in each group and the Pearson test was performed for evidencing significant correlations. Differences were considered as significant when $\mathrm{p}$ values were below 0.05 .

\section{RESULTS AND DISCUSSION}

Homeorhesis is favored since mammary gland utilizes most of the nutrients and metabolites for the milk synthesis, almost regardless of the other body needs (Bauman and Currie 1980). This situation is characterized by NEB, which is the major driving force for substantional endocrine, metabolic and body condition changes. Homeorhesis provoke intense lipid mobilization which characterized by high NEFA concentrations starts within high pregnancy and reaches a maximal intensity in the early lactation. NEFA are preferenti- ally and greatly accumulated as TG in the liver, primarily because of a decrease in the very low density lipoproteins (VLDL) synthesis by hepatocytes and are used for intensive synthesis of ketone bodies in liver cells in ruminant. Ketone bodies (BHBA, acetone and acetoacetate) are intermediate metabolites of oxidation of NEFA (Aceves et al., 1985; Bell, 1995; Drackley, 1999; Cincovic et al., 2012).

Average concentration of variables of blood hormones and biochemical metabolites are examined and correlated in three groups. Results of blood hormones and biochemical metabolites for all examined groups of Simmental cows are shown in Table 2.

Correlations between hormones and biochemical metabolites calculated for all cows in this experiment are given in Table 3.

Results for GH concentrations in the Group 2, (early lactation cows) exhibited significantly increased $(\mathrm{P}<0.05)$ values, compared with Group 1 (late pregnant) and Group 3 (mid lactation cows). GH dramatically increase the mobilization of lipids from the adipose tissue and increase blood NEFA and BHB in early lactation cows (Tucker, 1994; Jindal and Ludri, 1994). According obtaining results, GH was significant $(\mathrm{P}<0.05)$ positively correlated with NEFA in this research. These correlations have been reported by other authors (Jindal and Ludri, 1994; Balogh et al., 2008) and show that under NEB conditions, blood GH concentration increases, resulting with fat lipomobilization, 
and stimulating milk yield in dairy cows during lactation. (Bonczek et al., 1988; Bauman and
Vernon, 1993; Lucy et al., 2001; Butler et al., 2003).

Table 2

Blood metabolic hormones and metabolites in late pregnant, early and mid lactation dairy cows ( $n=15$ in each group).

\begin{tabular}{lcccc}
\hline \hline & Late pregnant cows & Early lactation cows & Mid lactation cows & p-value \\
\hline GH (ng/ml) & $11.74 \pm 8.67^{\mathrm{a}}$ & $17.13 \pm 3.87^{\mathrm{abc}}$ & $11.45 \pm 4.42^{\mathrm{b}}$ & 0.0634 \\
Insulin(ng/ml) & $5.52 \pm 0.44^{\mathrm{a}}$ & $3.93 \pm 2.14^{\mathrm{b}}$ & $6.54 \pm 4.71^{\mathrm{c}}$ & 0.1823 \\
$\mathrm{~T} 3(\mathrm{ng} / \mathrm{ml})$ & $0.77 \pm 0.36^{\mathrm{a}}$ & $0.73 \pm 0.41^{\mathrm{b}}$ & $1.29 \pm 1.01^{\mathrm{abc}}$ & 0.0466 \\
T4 (ng/ml) & $32.70 \pm 13.67^{\mathrm{a}}$ & $31.93 \pm 18.30^{\mathrm{b}}$ & $33.06 \pm 17.04^{\mathrm{c}}$ & 0.9801 \\
Glucose (mmol/l) & $3.35 \pm 0.32^{\mathrm{a}}$ & $2.29 \pm 0.48^{\mathrm{abc}}$ & $2.75 \pm 0.43^{\mathrm{ac}}$ & 0.0000 \\
BHB (mmol/l) & $1.17 \pm 0.36^{\mathrm{a}}$ & $1.59 \pm 0.25^{\mathrm{abc}}$ & $0.91 \pm 0.16^{\mathrm{a}}$ & 0.0000 \\
$\mathrm{NEFA}(\mathrm{mmol} / \mathrm{l})$ & $0.17 \pm 0.06^{\mathrm{a}}$ & $0.40 \pm 0.28^{\mathrm{abc}}$ & $0.13 \pm 0.04^{\mathrm{c}}$ & 0.0002 \\
TG (mmol/l) & $0.28 \pm 0.07^{\mathrm{abc}}$ & $0.12 \pm 0.02^{\mathrm{b}}$ & $0.15 \pm 0.04^{\mathrm{c}}$ & 0.0000 \\
\hline \hline
\end{tabular}

Legend: Values marked by letters ( $a, b, c)$ in one row describe significant differences $(p<0.05)$.

Table 3

Correlation coefficients between metabolic hormones and metabolites calculated for all cows

\begin{tabular}{lccccccc}
\hline & Insulin & T3 & T4 & glucose & BHB & NEFA & TG \\
\hline GH & $r=0.16$ & $r=-0.08$ & $r=-0.16$ & $r=-0.21$ & $r=0.28$ & $r=0.35^{*}$ & $r=-0.10$ \\
insulin & & $r=0.37^{*}$ & $r=0.08$ & $r=-0.03$ & $r=0.28$ & $r=-0.23$ & $r=0.10$ \\
T3 & & $r=0.31^{*}$ & $r=-0.01$ & $r=-0.19$ & $r=-0.21$ & $r=-0.12$ \\
T4 & & & $r=-0.03$ & $r=-0.05$ & $r=-0.18$ & $r=-0.06$ \\
glucose & & & & $r=-0.45^{*}$ & $r=-0.35^{*}$ & $r=0.63^{*}$ \\
BHB & & & & & $r=0.39^{*}$ & $r=-0.32^{*}$ \\
NEFA & & & & & & & $r=-0.21$ \\
\hline \hline
\end{tabular}

Legend: significant correlation $(P<0.05)$ are marked with an asteriks $\left(^{*}\right)$

Blood insulin values during the same period were nonsignificant $(\mathrm{P}>0.05)$ lower in Group 2 (early lactation cows) compared with Group 1 (late-pregnant) and Group 3 (mid lactation cows). Decrease blood insulin concentration under NEB, reduced dry matter intake, while increasing blood $\mathrm{GH}$ values, provoke elevation of serum NEFA and BHB. This serum changes of metabolites suggest for reduced anabolic effect of insulin on lipid metabolism resulting with sudden uncontrolled mobilization of NEFA from body reserves and ketogenesis in the liver. Similar results were obtained by other authors (Bonczek et al., 1988; Veenhuizen et al., 1991; Jindal and Ludri, 1994; Butler et al.,
2003). Blood levels of thyroid hormones T3 $(\mathrm{p}<0.05)$ and $\mathrm{T} 4(\mathrm{p}>0.05)$ in Group 1 (late pregnancy) and Group 2 (early lactation) were significant lower compared with Group 3 (mid lactation). These results are comply with other authors (Aceves et al., 1985; Jindal and Ludri, 1994; Tiirats, 1997; Huszenicza et al., 2002; Djoković et al., 2007) suggesting that concentration of thyroid hormones are changes as a result of adaptation process of high energy demand of udder and it could be reason for metabolic disorders. During early stage of lactation blood NEFA and BHB were significantly higher $(\mathrm{p}<0.05)$ than in late pregnancy and mid lactation cows. BHB values were higher than ref- 
erence values in early lactation cows $(0.16-0.85$ $\mathrm{mmol} / \mathrm{l}$ ), while NEFA values were within physiological range $(0.01-0.52 \mathrm{mmol} / \mathrm{l})$, (Van Saun, 2004). Blood NEFA and BHB concentrations have significantly $(\mathrm{p}<0.05)$ positively correlation. Reist et al., (2002) reported a strong negative correlation between blood NEFA and BHB concentrations and NEB in early lactation cows. Blood glucose values in late pregnant and mid lactation cows were within physiological range $2.5-4.2 \mathrm{mmol} / \mathrm{l}$ (Radostits et al., 2000), while hypoglycemia (2.29 $\pm 0.48 \mathrm{mmol} / \mathrm{l}$ ) was find in early lactation cows. Additionally, significant negative correlation $(\mathrm{p}<0.05)$ was determined between plasma glucose levels with serum levels of NEFA and BHB. Cows in NEB have low rates of glucose and high levels of BHB (Sevinc et al., 2003). Serum levels of glucose, TG, total cholesterol, TP, albumin and urea are indicators of impaired hepatic function (Veenhuizen et al., 1991; Sevinc et al., 2003; Djoković et al., 2007) and decrease concentration of metabolic parameters may imply on fatty liver condition. Present results of serum concentration of glucose and TG in early stage lactation cows, were significantly lower $(\mathrm{p}<0.05)$ compared with late pregnant and mid lactation cows. Also, significant positive correlation $(\mathrm{p}<0.05)$ was determined between glucose and TG, which shows that under steatotic conditions, endogenous liver gluconeogenesis synthesis declines, resulting in reduced levels of blood glucose and TG (Sevinc et al., 2003).

This study showed the possibility for fatty liver developing in early stage lactation in the Simmental cows. Possible alterations in the liver function may have deleterious effects on the metabolism of Simmental cows and possibility for adversely impact milk production or reproduction.

\section{CONCLUSION}

These changes are due to metabolic pathways such as lipolysis and ketogenesis occurring during homeorhetic processes and liver adaptation during early stage lactation in the Simmental cows, which may lead to metabolic disturbance in early stage lactation. These hormonal and metabolic changes can be used as indicators of the metabolic and endocrine status of Simmental cows.

Acknowledgment: This study was financially supported by the Ministry of Education and Science, Republic of Serbia, Project TR 31001.

\section{REFERENCES}

[1] Aceves C., Ruiz A., Romero C., Valverde C. (1985): Homeorhesis during early lactation. Euthyroid sick-like syndrome in lactating cows. Acta Endocrinologica, 110: 505-509.

[2] Balogh O., Szepes O., Kovacs K., Kukcasas M., Reiczige J., Alcazari J.A., Keresztes M., Febel H., Bartyik J., Fekete S., Fesus L., Huszenicza Gy. (2008): Interrelationships of growth hormone Alu I polymorphism, insulin resistance, milk production and reproductive performance in Holstein-Friesian cows. Veterinarni Medicina, 53: 604-616.

[3] Bauman E., Currie W. (1980): Partitioning of nutrients during pregnancy and lactation. A review of mechanisms involving homeostasis and homeorhesis. Journal of Dairy Science, 63:1514-1518.

[4] Bauman D. E., Vernon R. G. (1993): Effects of bovine somatotropin on lactation. Annual Review of Nutrition, 13: 437-461.

[5] Bell A. W. (1995): Regulation of organic nutrient metabolism during transition from late pregnancy to early lactation. Journal of Animal Science, 73: 2804-2819.

[6] Bonczek R. R., Young S. W., Wheaton J. E., Miller K. P. (1988): Responses of somatotropin, insulin, prolactin and thyroxine to secretion for milk yield in Holsteins. Journal of Dairy Science, 71: 2470-2475.

[7] Butler S. T., Marr A. L., Pelton S. H., Radcliff R. P., Lucy M. C., Butler W. R. (2003): Insulin restores GH responsiveness during lactation-induced negative energy balance in dairy cattle: Effects on expression of IGF-I and GH receptor 1A. Journal of Endocrinology, 176: 205-217.

[8] Cincović R.M., Belić B, Radojčić B., Hristov S., Đoković R. (2012): Influence of lipolysis and ketogenesis to metabolic and hematological parameters in dairy cows during periparturient period. Acta Veterinaria, Beograd, 62: 429-444,

[9] Civelek T., Aydin I., Cingi C., Yilmaz O., Kabu M. (2011): Serum non-esterified fatty acids and betahydroxybutyrate in dairy cows with retained placenta. Pakistan Veterinary Journal, 31: 341-344.

[10] Drackley J. K. (1999): Biology of dairy cows during the transition period: The final frontier? Journal of Dairy Science, 82: 2259-2273.

[11] Djoković R., Šamanc H., Jovanović M., Nikolić Z. (2007): Blood concentrations of thyroid hormones and lipids in the liver in dairy cows in transitional period. Acta Veterinaria Brno, 76: 525-532.

[12] Ferguson J. D., Galligan D. T., Thomsen N. (1994): Principal descriptors of body condition score in Holstein cows. Journal of Dairy Science, 77: 2695-2703.

[13] Gonzalez F.D., Muino R., V. Pereira V., Campos R. (2011): Relationship among blood indicators of lipomobilization and hepatic function during early lactation in high-yielding dairy cows. Journal of Veterinary Science, 12: 251-255.

[14] Huszenicza Gy., Kulcsar M., Rudas P. (2002): Clinical endocrinology of thyroid gland function in ruminants: A review of literature. Veterinarni Medicina, 47: 191-202.

[15] Jindal S. K., Lundri R. S. (1994): Relationship between some hormones, metabolites and milk yield in lactating 
crossbred cows and buffaloes. Asian-Austalian Journal of Animal Science, 7: 239-248.

[16] Lucy M. C, Hauser S. D., Eppard P. J., Krivi G. G., Clark J. H., Bauman D. E., Collier R. J. (2001): Variants of somatotropin in cattle: gene frequencies in major dairy breeds and associated milk production. Domestic Animal Endocrinology, 10: 325-333.

[17] Oetzel G. R. (2004): Monitoring and testing dairy herds for metabolic disease. Veterinary Clinic of North America: Food Animal Practice, 20: 651-674.

[18] Radostits O. M., Blood D. C., Gay C. C., Hinchcliff K. W. (2000): Veterinary Medicine, A Textbook of the Diseases of Cattle, Sheep, Pigs, Goats and Horses. Ninth Edition W.B. Saunders Company Ltd London, New York, Philadelphia, San Francisco, St. Louis, Sydney

[19] Reist M., Erdin D., Von Euw D., Tschuemperlin K., Leuenberger H., Delavaud C., Chilliard Y., Hammo H. M., Morel C., Philipona C., Zbinden B Y., Kuenzi N., Blum J. W. (2002): Estimation of energy balance at the individual and herd level using blood and milk traits in high-yielding dairy cows. Journal of Dairy Science, 85: 3314-3327.

[20] Sevinc M., Basoglu A., Guzulbekta H. (2003): Lipid and lipoprotein levels in dairy cows with fatty liver. Turkish Journal of Veterinary and Animal Science 27: 295-299.

[21] Tiirats T. (1997): Thyroxine, triiodothyronine and reverse-triiodothyronine concentrations in blood plasma in relation to lactational stage, milk yield, energy and dietary protein intake in Estonian dairy cows. Acta Veterinaria Scandinavica, 38: 339-348.

[22] Tucker H. A. (1994): Lactation and its hormonal control. Pages 2235-2263 in The Physiology of Reproduction. E. Knobil and J. D. Neill, ed. Raven Press Ltd, New York

[23] Van Saun R. J. (2004): Metabolic Profiling. U: Andrews A. H. (ur.) Bovine Medicine Diseases and Husbandry of Cattle. Journal Blackwell Science, 153-159.

[24] Veenhuizen J. J., Drackley J. K., Richard M. J., Sanderson T. P., Miller L. D., Young J. W. (1991): Metabolic changes in blood and liver during development and early treatment of experimental fatty liver and ketosis in cows. Journal of Dairy Science, 74: 4238-4253. 